\title{
Regional security institutions do contribute significantly to the maintenance of peace and stability in the Asia Pacific region
}

Jason Leong

\section{Introduction}

Today, we can observe that there is relative peace and stability in the Asia Pacific region. There remains traditional security flashpoints such as the South China Sea, Taiwan and North Korea, which could challenge the current peace and stable regional order. More recent issues such as energy security, transnational crime and human security add to these growing challenges. ${ }^{1}$ In an increasingly globalised world, the challenges faced by the Asia Pacific region are large, involve many countries and therefore require a multilateral approach to resolve.

Pre-1990s, in the Asia Pacific there was very little formal regional security dialogue. ${ }^{2}$ Then in 1994, the ASEAN Regional Forum (ARF), one of the most prominent regional security institutions in the Asia Pacific region,

\footnotetext{
1 Katja Weber, 'The ASEAN Regional Forum and Security Governance in the Asia-Pacific' (paper presented at the EUSA Eleventh Biennial International Conference, Marina Del Rey, California, 23-25 April 2009), 10.

2 Brendan Taylor, Security Cooperation in the Asia-Pacific Region in History as Policy: Framing the Debate on the Future of Australia's Defence Policy, ed. Ron Huisken and Meredith Thatcher, (Canberra: ANU E Press, 2007), 117.
} 
was formed. ${ }^{3}$ This reflected a shift of emphasis to regional institutions to tackle multilateral issues. This paper will use the ARF as a major case study in analysing the contributions of regional security institutions to peace and stability in the region. Two other institutions, the Association of Southeast Asian Nations (ASEAN), and the Council of Security and Cooperation in the Asia Pacific (CSCAP), will be discussed to an extent.

\section{Thesis}

Using the specific regional security institutions as an example, this paper will argue that these institutions have contributed significantly to the maintenance of peace and stability that is present in the region today. The institutions have been significantly engaging major powers, enhancing cooperation between states and building confidence through a 'soft' leadership style. This has been successful in maintaining peace and stability until now. However, the future prospects later discussed will require these institutions to become more proactive to remain relevant.

\section{How do the institutions contribute to peace and stability?}

In analysing the contributions of the three institutions, we must remember that diplomacy in the Asia Pacific region differs from that of other regions. In particular, the philosophy that ASEAN attempts to implement is one based on the 'ASEAN Way'. ${ }^{4}$ Briefly, the ASEAN Way is informal diplomacy built on cooperation and conflict avoidance, ${ }^{5}$ consensus, and respect for sovereignty. ${ }^{6}$ The following sections will look at the institutions' contributions through the lens of the ASEAN Way.

3 'ASEAN Regional Forum', Department of Foreign Affairs and Trade, Australia, accessed 27 May 2015, dfat.gov.au/international-relations/regional-architecture/asean/Pages/aseanregional-forum-arf.aspx.

4 Colonel Georgeina Whelan, 'Does the ARF have a Role in ASEAN's Pursuit of Regional Security in the Next Decade?' (paper presented at the Centre for Defence and Strategic Studies at the Australian Defence College, 2009), 11.

5 Ralf Emmers, Cooperative Security and the Balance of Power in the ASEAN and the ARF, (New York: RoutledgeCurzon, 2003), 23.

6 Weber, 'The ASEAN Regional Forum', 8. 


\section{Engaging major powers}

Engaging the United States and China in a regional security dialogue has had positive benefits towards building peace and stability in the muchcontested Asia Pacific region. Most of the individual states in the region are too small to face either the US or China on their own. In a multilateral sphere, smaller states are able to keep both the US and China balanced against each other, and at the same time promote norms of cooperation and interdependence. Evelyn Goh terms this strategy as 'enmeshment', involving the major powers in deep, sustained relationships eventually leading to integration. ${ }^{7}$

ASEAN is successful in its engagement with China because the norms built within the ASEAN Way suits China, which has a common interest in nonintervention policies. ${ }^{8}$ ASEAN's partnership with China is notable in the economical aspect, with the trade liberalisation of goods and services, as well as the signing of free trade agreements (FTAs). ${ }^{9}$ These policies would certainly lead to economic interdependence with both sides having a stake in maintaining the peace to ensure trade from both sides continues. From a liberalist perspective, this cooperation and interdependence is significant in maintaining a peaceful and stable region.

This enmeshment of the major powers is an effective strategy even from a realist perspective. In a region where states such as China view Japan and the United States with distrust, dialogue is still possible as the major powers view ASEAN and the ARF as impartial. ${ }^{10}$ The strategic enmeshment involving opposing powers like China and Japan effectively puts both states in a power balance. Douglas Webber argues that this balance means if one of them attempts to aggressively display leadership, it risks facing a balancing coalition against it. ${ }^{11}$ In effect, this means the costs of aggression would weigh heavily against any benefits. Brendan Taylor suggests that

7 Evelyn Goh, 'Great Powers and Southeast Asian Regional Security Strategies: OmniEnmeshment, Balancing and Hierarchical Order', (Singapore: Institute of Defence and Strategic Studies, 2005).

8 Douglas Webber, 'The Regional Integration that Didn't Happen: Cooperation Without Integration in the Early Twenty-First Century East Asia', The Pacific Review, Vol. 23, Issue 3 (2010): 323-324.

9 Webber, 'Regional Integration', 318.

10 Webber, 'Regional Integration', 323.

11 Ibid., 323-24. 
this enmeshment has also dampened concerns about an aggressive rise of China. ${ }^{12}$ By balancing the major powers and increasing the costs associated with aggression, ASEAN and the ARF have managed to shape a stable regional order.

The ARF engagement with the US is also strategically useful in maintaining a stable regional order. It engages the US by presenting itself as a low risk, non-threatening institution. ${ }^{13}$ This paper believes it allows the US to maintain its interests in the region whilst not committing to serious binding military commitments. It is also a way to reassure allies that the US is still engaged in the Asia Pacific region. ${ }^{14}$ This thus leads to the effect of containing the rise of China by ensuring there is appropriate competition in the region. ${ }^{15}$ This competition is evident in the example of FTAs, seen when the US announced talks for a FTA with ASEAN in 2000, with China followed by opening a FTA negotiation with ASEAN in 2001. ${ }^{16}$

The enmeshment strategy therefore is one of the primary contributions of the ARF and ASEAN. It brings together different states that harbour some distrust about each other ${ }^{17}$ into a sphere of cooperation and interdependence that balances the power possessed by major states and helps maintain peace and stability in the region.

\section{'Soft' leadership style}

Following on the theme of cooperation, the ARF is successful in maintaining relative peace and stability using what is a 'soft' leadership style. This style focuses more on co-opting states rather than coercing them through pressure, threats or sanctions, which is a hard leadership

12 Taylor, 'Security Cooperation in the Asia Pacific', 122.

13 Alice D. Ba, 'Regional Security in East Asia: ASEAN's Value Added and Limitations', in Journal of Current Southeast Asian Affairs, Vol. 29, No. 3, (2010): 117.

14 John Duffield, 'Why Is There No APTO? Why Is There No OSCAP?: Asia-Pacific Security Institutions in Comparative Perspective', Contemporary Security Policy, Vol. 22, Issue 2 (2001): 77.

15 Ibid., 80.

16 Goh, 'Great Powers', 5.

$17 \mathrm{Ba}$, 'Regional Security', 116-17. 
style. ${ }^{18}$ Some of the main ways that the ARF exercises its soft power is by sharing common norms, adopting confidence-building measures (CBMs), and opening opportunities for dialogue. ${ }^{19}$

\section{Spreading norms}

The ASEAN style norms of cooperation and consensus builds positive and peaceful relations between states. This is beneficial to maintaining peace and stability in the region. The ARF, being parented by ASEAN nations, ensured that security framework was heavily influenced by ASEAN norms. ${ }^{20}$ By engaging major powers in ASEAN norms of cooperation and consensus, it builds a sense of common purpose and mutual confidence. ${ }^{21}$ This sets the tone for peaceful relations between different states, especially between ASEAN states. To take an example, the motto of ASEAN is 'One Vision, One Identity, One Community'. ${ }^{22}$ This idea of a common identity reconciles and integrates otherwise different states to a sense of common purpose for peace. Although it is questionable whether there really is an 'ASEAN identity' because of the different cultures, languages and prejudices between states. ${ }^{23}$ Nonetheless, Taylor notes that this striving for a sense of unity has made what he describes as a 'shooting war' between ASEAN states, an unthinkable situation. It can thus be argued that ASEAN and the ARF are attempting to promote this common identity, first within itself and then to its other members to build peaceful relationships.

\section{Confidence-building measures}

One of the more common initiatives employed by the ARF is confidencebuilding measures (CBMs). CBMs are broadly defined as any set of unilateral, bilateral or multilateral actions that act to reduce military tensions between states. ${ }^{24}$ These measures build confidence between parties and states and increases interdependence between states. This occurs because

18 Joseph Nye, '5 Leadership Lessons: Joseph Nye on Leadership', www.leadershipnow. com/leadingblog/2010/07/5_leadership_lessons_joseph_ny.html.

19 Whelan, 'Does the ARF have a Role', 10.

20 Ibid., 14.

21 Taylor, 'Security Cooperation in the Asia-Pacific', 123.

22 ASEAN Motto. www.asean.org/asean/about-asean/asean-motto.

23 John Patrick Allengui, 'Is an ASEAN Identity Possible?' (2015), www.rappler.com/ move-ph/ispeak/87163-asean-identity-possible.

24 Holly Higgins, 'Applying Confidence-Building Measures in a Regional Context' (paper presented to Institute for Science and International Security, 2002), 109. 
CBMs consist of information sharing, notification of military exercises and exchanges between scholars, military and civilian government personnel, among others. ${ }^{25}$

One success in the ARF's confidence-building measures is facilitating dialogue between North and South Korea, who would otherwise be ill prepared to make arrangements between each other. ${ }^{26}$ The establishment of prominent Track II informal dialogues through institutions like the CSCAP and the Network of ASEAN Defence Institutes (NADI), could also be seen as CBMs. Track II dialogue do not restrict participating officials to state policy and allow different perspectives to be put forward. These forums provide an arena for building confidence, and discussing security issues beyond official governmental positions.$^{27}$ Track II institutions also provide a stable channel to manage tensions, and mediate dialogue between states in situations when there is a lack of mutual trust (for example, Taiwan Strait issues). ${ }^{28}$ These CBMs have been noted to increase trust between ARF participants, ${ }^{29}$ which the ARF seeks to use to promote lasting peace. ${ }^{30}$

More concrete progress has also been made in other non-traditional security issues such as energy security and climate change. In the area of energy security, the ARF has facilitated greater cooperation through information exchange, sharing of best practices and mutual investment. ${ }^{31}$ In late 2009, ASEAN with China, Japan and South Korea also solidified cooperation in working-level talks to initiate oil-stockpiling plans. ${ }^{32}$ ASEAN has also demonstrated significant contributions towards combating climate change. A noteworthy example is the Singapore Declaration on Climate Change,

25 Acharya, 'The ASEAN Regional Forum: Confidence-Building', 8-9.

26 Higgins, 'Applying Confidence-Building Measures', 117.

27 Secretariat of NADI, www.rsis.edu.sg/nadi/.

28 Chyungly Lee, 'Cross-Strait Participation in the Council for Security Cooperation in the Asia-Pacific: A Case Study of a Multilateral Track Two Approach to Conflict Prevention', Issues \& Studies, Vol. 45, No. 4 (2009), Institute of International Relations, National Chengchi University.

29 ASEAN Regional Forum, Co-Chair Summary Report from Workshop on 'ConfidenceBuilding Measures and Preventive Diplomacy in Asia and Europe' (2008).

30 Weber, 'The ASEAN Regional Forum', 12.

31 Ibid., 17.

32 Mely Caballero-Anthony, 'Non Traditional Security Issues in Asia: Imperatives for Deepening Regional Security Cooperation' in Assessing Track 2 Diplomacy in the Asia-Pacific Region: A CSCAP Reader, ed. Desmond Ball and Chong G. Kwa (2010), 213. 
Energy and Environment adopted in 2007. ${ }^{33}$ Another initiative is the ASEAN Multi-Sectoral Framework on Climate Change and Food Security adopted in $2009 .{ }^{34}$ These two examples showcase policy coordination and can be interpreted as different states recognising common goals and interests. This kind of cooperation is useful in maintaining peace and stability.

\section{Opportunities for dialogue}

Naturally, many opportunities to facilitate dialogue arise with better trust and cooperation, confidence-building measures and strong engagement with different states. As with the North and South Korea example above, states that would otherwise be unwilling to have dialogues, are likely to find multilateral institutions impartial and a useful avenue for discussion. Taylor notes further examples of such dialogues, held between the US and North Korea in 2004, and between China and Japan in 2006, both facilitated by the ARF or due to their participation in the ARF. ${ }^{35}$ Without such an avenue, mistrust could easily develop, with different political rhetoric present. But this lack of trust can be overcome with the discussion of what are usually highly sensitive and controversial issues in such dialogues. ${ }^{36}$

The opportunities for dialogue between officials and policymakers have the potential to continue building confidence and engaging different states. The CSCAP has been noted to be extraordinary in its achievements towards dialogue. ${ }^{37}$ CSCAP's participation is made up of academics, thinktank analysts and policymakers who engage in free discussion of security issues. ${ }^{38}$ By including different states in a regional dialogue, it works to act as a barrier to conflict. As Lee notes, the inclusive membership of CSCAP in a regional dialogue process, inherently implies the utility of conflict prevention. ${ }^{39}$

\footnotetext{
33 Ibid., 206.

34 Ibid.

35 Taylor, 'Security Cooperation in the Asia-Pacific', 122.

36 Ibid., 123.

37 Barry Desker, 'CSCAP: Shaping the Future of the ASEAN Regional Forum' in Assessing Track 2 Diplomacy in the Asia-Pacific Region: A CSCAP Reader, ed. Desmond Ball and Chong G. Kwa (2010), 2.

38 Ibid., 231.

39 Lee, 'Cross Strait Participation',192.
} 
A similar analogy about inclusive membership could be drawn for the ARF, but there is also a mutual lack of trust between regional powers. Therefore, a Track II institution like CSCAP contributes significantly in bringing together experts in their private capacities who are more welcoming and feasible. ${ }^{40}$

\section{Conclusion}

Desker notes that the combination of engagement and enmeshment strategies of the ARF, and the willingness of major powers to respond to those strategies, make the likelihood of continuing peace and stability very promising. ${ }^{41}$ This paper agrees with that idea. The enmeshment strategy and the soft leadership style used by the ASEAN states within the ARF has worked towards integrating the major powers, making them feel as if they have a stake in peace and stability in the region. Through confidencebuilding measures, dialogue and cooperation mechanisms and initiatives, a sense of common purpose and interdependence overall has helped the ARF maintain peace and stability in the region.

\section{Limits of regional security institutions}

One of the main criticisms of the ARF is that it lacks the ability to respond to conflicts or any major crises. ${ }^{42}$ This criticism arises mainly from the major powers. Narine notes that there is a distinct difference in expectations between Western states and ASEAN of what the ARF should achieve. ${ }^{43}$ The ARF still remains in the confidence-building stage after a decade of establishment, ${ }^{44}$ possibly because the consensual style of dialogue makes any form of progress too slow. ${ }^{45}$ Cooperation and compromise is not as easy

40 Ibid., 194.

41 Desker, 'CSCAP: Shaping the Future', 227.

42 Taylor, 'Security Cooperation in the Asia-Pacific', 122.

43 Shaun Narine, 'ASEAN and the ARF: The Limits of the ASEAN Way', Asian Survey, Vol.

37, No. 10, (University of California Press, October 1997): 964.

44 Weber, 'The ASEAN Regional Forum', 19.

45 Taylor, 'Security Cooperation in the Asia-Pacific', 122. 
to achieve with the number of different countries involved in the ARF. Also, unlike smaller ASEAN states, great powers are unlikely to cooperate, as it might expose weakness. ${ }^{46}$

A counter to this criticism is that the great powers usually would find themselves in a position where they will lose if they choose not to cooperate or compromise. Firstly, analysts note that major powers decided to join the ARF to avoid being left out in the first place. ${ }^{47}$ They would likely be left out if they decided to take an uncompromising stance, or in another case, if they display aggressive leadership, it risks facing a balancing coalition from other states (as discussed in the 'Engaging Major Powers' subsection). Secondly, the ARF as an institution provides many benefits for cooperation. It fulfils the role of an institution that lowers costs, provides information and is a welcome setting for states that have mutual lack of trust. ${ }^{48}$ Weber notes that the ARF has clearly promoted stability through CBMs, trust building and exchange of ideas. While it may not be the coercive militarystrong institution Western states seek, the ARF may be better off with its soft leadership style, one that has proven suitable to the region.

\section{Future prospects}

Despite the limitations and challenges, the contributions of the ARF cannot be overlooked. Willingness to hold dialogue and engage is the first step towards any substantive progress. ${ }^{49}$ But the criticism of the ARF's inability to respond to conflict, and its being nothing more than a 'talk shop', ${ }^{50}$ must be considered. As political issues are becoming more transnational, existing arrangements relying on the ASEAN Way of diplomacy may not be sufficient..$^{51}$

\footnotetext{
46 Narine, 'ASEAN and the ARF', 975.

47 Weber, 'The ASEAN Regional Forum', 21; Narine, 'ASEAN and the ARF', 975.

48 Weber, 'The ASEAN Regional Forum', 21.

49 Ba, 'Regional Security', 127.

50 Taylor, 'Security Cooperation in the Asia-Pacific', 122.

51 Webber, 'Regional Cooperation', 330.
} 
The emphasis on achieving a consensus has already frustrated Western states, and moving at the speed of the lowest common denominator is seen as unreliable for the future ${ }^{52}$ Philippine analyst Raymond Jose G. Quilop notes that suggestions have been made to leave behind achieving consensus and utilising a coalition of the willing. ${ }^{53}$ Such change of process and reform would take quite a while to achieve, based on the willingness of the states. Weber argues that from the history of the region, countries are sensitive to such curtailing of their freedom of action. ${ }^{54}$ However, it is clear that such criticism must be addressed if the ARF wants to remain relevant in the future, ${ }^{55}$ and continue to maintain peace and stability in the region.

\section{Conclusion}

Regardless of how successful an institution is, it has to consistently adapt with the times. In an increasingly globalised world with transnational challenges, the ARF as a regional security institution has contributed significantly to maintaining peace and stability. The ARF achieves this by engaging major powers and different states, enhancing cooperation and exercising soft leadership. These actions build confidence, a common sense of purpose and interest in a peaceful region. Although this soft leadership style has certain limits and has been subject to some criticism, this does not necessarily mean that the ARF is unable to maintain peace and stability. Rather, the ARF will need to continuously adapt in the future to remain a relevant key actor in maintaining peace and stability, as it already does today.

52 Raymund Jose G. Quilop, 'Preventive Diplomacy in the Asia-Pacific: Challenges and Prospects for the ASEAN Regional Forum' (University of the Philippines, 2003), 76.

53 Ibid., 77.

54 Weber, 'The ASEAN Regional Forum', 24.

$55 \mathrm{Ba}$, 'Regional Security', 129. 


\section{References}

Acharya, Amitav. N.d. 'The ASEAN Regional Forum: ConfidenceBuilding', 32. www.amitavacharya.com/sites/default/files/ASEAN $\% 20$ Regional\%20Forum-Confidence\% 20Building.pdf.

Allengui, John Patrick. 'Is an ASEAN Identity Possible?' (2015), www. rappler.com/move-ph/ispeak/87163-asean-identity-possible.

ASEAN Motto. www.asean.org/asean/about-asean/asean-motto.

ASEAN Regional Forum, Co-Chair Summary Report from Workshop on Confidence-Building Measures and Preventive Diplomacy in Asia and Europe, (2008).

Ba, Alice D. ‘Regional Security in East Asia: ASEAN's Value Added and Limitations', Journal of Current Southeast Asian Affairs, Vol. 29, No. 3 (2010): 115-30.

Caballero-Anthony, Mely. 'Non Traditional Security Issues in Asia: Imperatives for Deepening Regional Security Cooperation' in Assessing Track 2 Diplomacy in the Asia-Pacific Region: A CSCAP Reader, edited by Desmond Ball and Chong G. Kwa. (S. Rajaratnam School of International Studies, 2010), 202-18.

Desker, Barry. 2010. 'CSCAP: Shaping the Future of the ASEAN Regional Forum' in Assessing Track 2 Diplomacy in the Asia-Pacific Region: A CSCAP Reader, edited by Desmond Ball and Chong G. Kwa (S. Rajaratnam School of International Studies), 227-39.

Duffield, John. 'Why is there no APTO? Why is there no OSCAP?: Asia-Pacific security institutions in comparative perspective', Contemporary Security Policy, Vol. 22, Issue 2 (2001): 69-95, DOI: 10.1080/13523260512331391148.

Emmers, Ralf. Cooperative Security and the Balance of Power in the ASEAN and the ARF, (New York: RoutledgeCurzon, 2003), 23.

Goh, Evelyn. 'Great Powers and Southeast Asian Regional Security Strategies: Omni-Enmeshment, Balancing and Hierarchical Order', (Singapore: Institute of Defence and Strategic Studies, 2005). 
Higgins, Holly. 'Applying Confidence-Building Measures in a Regional Context', paper presented to Institute for Science and International Security (2002), 109-17.

Lee, Chyungly. 'Cross Strait Participation in the Council for Security Cooperation in the Asia-Pacific: A Case of Study of a Multilateral Track Two Approach to Conflict Prevention', Issues \& Studies, Vol. 45, No. 4 (Taiwan: Institute of International Relations, National Chengchi University, Taipei, 2009): 189-215.

Narine, Shaun. 'ASEAN and the ARF: The Limits of the ASEAN Way', Asian Survey, Vol. 37, No. 10, (University of California Press, October 1997), www.jstor.org/stable/2645616.

Nye, Joseph. '5 Leadership Lessons: Joseph Nye on Leadership' (2010), www.leadershipnow.com/leadingblog/2010/07/5_leadership_lessons_ joseph_ny.html.

Quilop, Raymund Jose G. 'Preventive Diplomacy in the Asia-Pacific: Challenges and Prospects for the ASEAN Regional Forum', (University of the Philippines, 2003).

Secretariat of NADI, www.rsis.edu.sg/nadi/.

Taylor, Brendan. 'Security Cooperation in the Asia-Pacific Region', in History as Policy: Framing the Debate on the Future of Australia's Defence Policy, edited by Ron Huisken, Meredith Thatcher (Canberra: ANU E Press, 2007), 117-28. press.anu.edu.au? $\mathrm{p}=68061$.

Webber, Douglas. 'The Regional Integration that Didn't Happen: Cooperation Without Integration in Early Twenty-first Century East Asia', The Pacific Review, Vol. 23, Issue 3 (2010): 313-33.

Weber, Katja. 'The ASEAN Regional Forum and Security Governance in the Asia-Pacific', paper presented at the EUSA Eleventh Biennial International Conference, Marina del Rey, CA, (Georgia Institute of Technology, 23-25 April 2009).

Whelan, Col. Georgeina. 'Does the ARF Have a Role in ASEAN's Pursuit of Regional Security in the Next Decade?' paper presented at the Centre for Defence and Strategic Studies at the Australian Defence College, (October 2012). 
This text is taken from Merici, Volume 1, 2015, edited by Henry Poetrodjojo, Ilze Alexander and Lauren Prossor, published 2016 by ANU eView, The Australian National University, Canberra, Australia. 